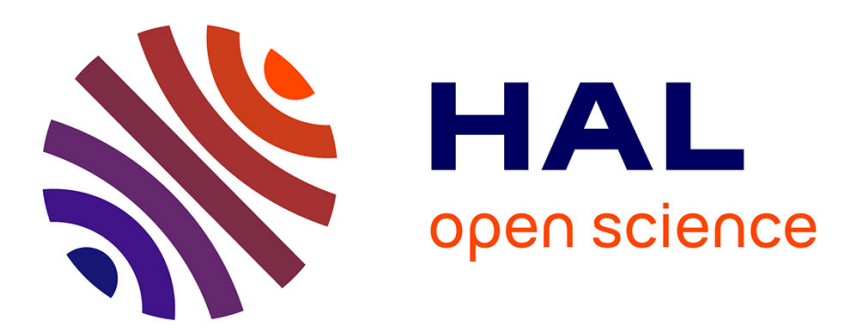

\title{
The Pique Then Reframe Technique: Replication and Extension of the Pique Technique
}

Nicolas Guéguen, Sébastien Meineri, Alexandre Pascual, Fabien Girandola

\section{To cite this version:}

Nicolas Guéguen, Sébastien Meineri, Alexandre Pascual, Fabien Girandola. The Pique Then Reframe Technique: Replication and Extension of the Pique Technique. Communication Research Reports, 2015, 32 (2), pp.143-148. 10.1080/08824096.2015.1016151 . hal-01960623

\section{HAL Id: hal-01960623 \\ https://hal.univ-rennes2.fr/hal-01960623}

Submitted on 19 Dec 2018

HAL is a multi-disciplinary open access archive for the deposit and dissemination of scientific research documents, whether they are published or not. The documents may come from teaching and research institutions in France or abroad, or from public or private research centers.
L'archive ouverte pluridisciplinaire HAL, est destinée au dépôt et à la diffusion de documents scientifiques de niveau recherche, publiés ou non, émanant des établissements d'enseignement et de recherche français ou étrangers, des laboratoires publics ou privés. 


\section{The Pique Then Reframe Technique: Replication and Extension of the Pique Technique}

Nicolas Guéguen, Sébastien Meineri, Alexandre Pascual \& Fabien Girandola

To cite this article: Nicolas Guéguen, Sébastien Meineri, Alexandre Pascual \& Fabien Girandola (2015) The Pique Then Reframe Technique: Replication and Extension of the Pique Technique, Communication Research Reports, 32:2, 143-148, DOI: 10.1080/08824096.2015.1016151

To link to this article: https://doi.org/10.1080/08824096.2015.1016151

\section{曲 Published online: 26 Mar 2015.}

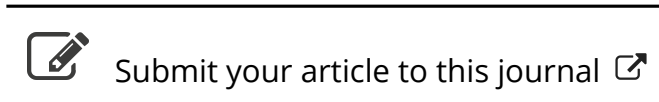

Џll Article views: 219

View Crossmark data ¿

Citing articles: 2 View citing articles $\longleftarrow$ 


\title{
The Pique Then Reframe Technique: Replication and Extension of the Pique Technique
}

\author{
Nicolas Guéguen, Sébastien Meineri, \\ Alexandre Pascual, \& Fabien Girandola
}

This study examined the pique technique associated with a reframing sentence. Passersby in the street were asked for money, either for a common amount of change (control) or 37 cents (pique technique). In half of the cases, the requester added a direct reframing sentence at the end of the request. Results showed that the pique technique increased compliance with the request. Adding a reframing sentence to the pique did not increase compliance rate with the request but increased the amount of money given by the participants. These results support the theoretical explanation that a reframing sentence could reduce the influence of the script of refusal activated by the money request.

Keywords: Compliance; Pique; Reframe; Request

For a long time, scientists have studied several procedures used for gaining compliance with a request (Marwell \& Schmitt, 1967; Miller, Boster, Roloff, \& Seibold, 1977; Pratkanis, 2007). Scientists have identified several techniques that lead individuals to comply more favorably with various requests. The more well-know techniques are the Foot-in-the-Door technique (Beaman, Cole, Preston, Klentz, \& MehrkensSteblay, 1983; Burger, 1999; Dillard, Hunter, \& Burgoon, 1984; Fern, Monroe, \& Avila, 1986), the Door-in-the-Face (Feeley, Anker, \& Aloe, 2012; O’Keefe \& Hale, 1998;

\footnotetext{
Nicolas Guéguen (PhD, University of Rennes 2, 1994) is Professor of Social Behavior at the University of Bretagne-Sud. Sébastien Meineri (PhD, University of Bretagne-Sud, 2009) is Associated Professor of Social Psychology at the University of Bretagne-Sud. Alexandre Pascual (PhD, University of Bordeaux 2, 2002) is Associated Professor of Social Psychology at the University of Bordeaux 2. Fabien Girandola (PhD, University of Provence, 1994) is Professor of Social Psychology at the University of Aix-Marseille. Correspondence: Nicolas Guéguen, Business Department, Université de Bretagne-Sud, Campus de Tohanic, 5600 Vannes, France; E-mail: nicolas.gueguen@univ-ubs.fr
} 
Pascual \& Guéguen, 2005), the Low-Ball (Burger \& Petty, 1981; Cialdini, Cacioppo, Basset, \& Miller, 1978; Guéguen, Pascual, \& Dagot, 2002), or Presence of Exchange (Jones, Doughty, \& Hickson, 2006).

One of these techniques, the "pique" technique, has received little interest. In the first study on this technique, Santos, Leve, and Pratkanis (1994) asked passersby for money using either a traditional request ("a quarter" or "some change") or an unusual "pique" request ("17 cents" or "37 cents"). They reported that the pique increased the compliance rate with the request but not the amount of money given by the participant. Burger, Hornisher, Martin, Newman, and Pringle (2007) reported an overall effect of the pique on compliance rate and also reported an increase in the amount of money given by the participant.

Santos et al. (1994) used two theoretical processes to explain their results. Based on a heuristic processing explanation, they suggested that the pique technique was effective to increase compliance because the unusual request disrupts the script of refusal activated when a solicitor asks for money. The authors also argued that the pique technique could have aroused the participant's curiosity and focused his/her attention on the unusual request. Such attention could have created a legitimization effect: Participants may have considered the unusual amount of money requested and decided that this request was legitimate, which in turn increased the participant's willingness to give money. In this study, we replicated the pique technique per se and examined the effect of ending the solicitation with a reframing sentence.

The disrupt-then-reframe technique (DTR), introduced by Davis and Knowles (1999), consists in using confusing phrasing or language in the first part of the request (the disrupt) and to follow it immediately with a reason to comply with the request (the reframe). The authors reported that stating the price of a package of note cards in pennies rather than in dollars ("They're 300 pennies ... that's \$3") and then adding the direct reframe ("It's a bargain") increased compliance with the request. A meta-analysis of the effectiveness of the DTR technique (Carpenter \& Boster, 2009) based on 14 studies published in six papers reported that the effect size of the increased probability of compliance associated with the DTR was larger than the effect size reported for other compliance-gaining procedures such as the foot-in-the-door (Dillard et al., 1984) or the door-in-the-face (O'Keefe \& Hale, 1998).

Davis and Knowles (1999), who were the first to report the effectiveness of the DTR technique for increasing compliance to a request, also found that neither the disrupt alone nor the reframe alone were sufficient to influence compliance. Such results could suggest that a reframe could exert an effect on the target only when the target was previously disrupted by the first sentence. Research reported that the effectiveness of some compliance-gaining procedures increased when a request or a sentence was added to the classic procedure. Dolinski (2000) and Goldman, Creaser, and McCall (1981) examined the factors influencing the effectiveness of the foot-in-the-door technique and reported that an intermediate request between the initial and the final request increased compliance with the final request more than when only the initial request was used. Recently, Guéguen et al. (2013) reported with 
the "evoking freedom" technique that telling someone twice when making a request that he/she was free to accept or to refuse the request increased compliance compared with a situation where the "freedom" sentence was used only once.

Our objective in the present study was to examine the effect of adding a reframe to the pique technique. Santos et al. (1994) stated that the pique technique may have acted as a disruption, which in turn increased compliance. Thus, it is posited that

H1: If a pique request is immediately followed by a direct reframe, more compliance will be obtained compared with the pique technique alone.

\section{Method}

\section{Participants}

The participants were 160 passersby walking alone in the street of a town situated on the southern coast of Brittany in France. All appeared to be between 25 and 60 years of age. They were distributed in four conditions according to a random distribution $(N=40$ per group).

\section{Procedure}

Three 19-20-year-old female undergraduate students in social management acted as solicitors. They were neatly dressed in a traditional way for young people of their age (jeans/sneakers/T-shirt). The experiment took place in a street on particularly sunny winter days. The solicitors were instructed to test a passerby in one of the four experimental conditions according to a prearranged order. The solicitor was instructed to approach the first adult (ranging in age from approximately 25 to 60 years) she saw walking alone. In the control condition, the solicitor approached the participant by saying: "Hello, can you spare a few coins, please?" In the pique condition, the solicitor asked in the same tone: "Hello, can you spare 37 cents, please?" In half of the cases (reframe condition), she added these words after her request "that would help me a lot." The solicitor then noted if the participant agreed or not to the request and if $s$ /he agreed, she waited for the money and measured the exact amount of money given by the participant.

\section{Results}

The 160 participants who complied with the request were defined as the first dependent variable. In the control condition, $15 \%(6 / 40)$ of the participants complied: $20 \%(8 / 40)$ in the reframe condition, $45 \%(18 / 40)$ in the pique condition, and $57.5 \%(23 / 40)$ in the pique + reframe condition. A chi-square test of independence revealed an overall statistical difference, $\chi^{2}(1)=21.80, p<.001, r=.35$. Pairwise comparisons showed that the pique condition was significantly different from the control condition, $\chi^{2}(1)=8.57, p=.003, r=.31$, and the reframe condition, $\chi^{2}(1)=5.70, p=.017, r=.26$, while the pique + reframe condition was statistically different from the control condition, $\chi^{2}(1)=15.63, p<.001, r=.40$, and the reframe 
condition, $\chi^{2}(1)=11.81, p=.001, r=.36$. However, neither the difference between the control condition and the reframe condition, $\chi^{2}(1)=0.34, p=.555, r=.06$, nor the difference between the pique condition and the pique + reframe condition, $\chi^{2}(1)=1.25, p=.263, r=.12$, was significant.

The mean amount of money given by the participants in the control condition was $M=0.13 €(S D=0.07), M=0.19 €(S D=0.25)$ in the reframe condition, $M=0.16 €$ $(S D=0.11)$ in the pique condition, and $M=0.37 €(S D=0.29)$ in the pique + reframe condition. A LSD test for multiple comparisons revealed that only the pique condition and the pique + reframe condition appeared significantly different $(p<.05)$.

\section{Discussion}

This field experiment study was conducted in a real-world setting and examined real behaviors. It found that, congruent with the findings reported by Burger et al. (2007) and Santos et al. (1994), the pique technique appeared to effectively increase compliance with the request. Moreover, the effect size of the difference appeared identical to those found in these two studies on this technique, suggesting the robustness of the technique. Congruent with the results reported by Davis and Knowles (1999), we found that the reframe-only condition did not increase compliance compared with the control condition. We did not observe that the pique + reframe condition significantly increased the rate of compliance with the request compared with the pique alone condition. However, it was found that the amount of money given by the participants increased.

Santos et al. (1994) proposed two theoretical explanations to explain the effectiveness of the pique technique. First, they argued that the pique technique disrupts the script of refusal. Second, the authors suggested that the pique could have aroused the participant's curiosity and focused his/her attention on the unusual request. Based on our results, the first theoretical proposition helps us to explain why the reframe added to the pique technique increased the amount of money given by the participants. Burger et al. (2007) reported that the pique technique appeared to be effective only with the participants who inquired about the unusual amount requested, regardless of whether the solicitor provided a specific or an uninformative reason. They also reported that in both the specific reason and the uninformative reason conditions, the average amount of money given by the participant was strictly the same as the amount of money requested by the solicitor. In our study, we also found that the amount of money given by the participants in the pique + reframe condition corresponded to the amount requested by the solicitor, suggesting that adding the reframe "that would help me a lot" could have acted as a reason given by the female requester. Thus, the reason could have increased the legitimacy of the request. Research has found that legitimizing a request increases compliance (Cialdini \& Schroeder, 1976), probably because it becomes more difficult for the participant to find a reason to refuse to help the solicitor. Thus, the reason activated by the reframe could act as an opposing argument (Allen, 1991) against the script of refusal that is probably activated when a stranger in a street asks someone for money. Fennis, Das, and Pruyn (2004) 
argued and found empirically that the DTR is an effective technique because it decreases participants' counterarguments. Overall, the reframe added to the pique technique could have weakened the participant's arguments to refuse, which in turn led him/her to give the solicitor more money. Thus, it would be interesting for future studies to examine if adding a reframe to the pique technique, and perhaps to other compliance techniques, could reduce the number of counterarguments to the request script.

This experiment has some limitations. The solicitors were not informed of the real objective of the study and previous research on this topic. However, they may have unconsciously behaved differently, which in turn influenced the participants' compliance. The experiment was conducted in France, while previous studies on the pique technique (Burger et al., 2007; Santos et al., 1994), were conducted in the United States. Thus, the generalization of the effect of a bow tie on behavior in other countries and cultures should be examined.

\section{References}

Allen, M. (1991). Meta-analysis comparing the persuasiveness of one-sided and two-sided messages. Western Journal of Speech Communication, 55, 390-404. doi:10.1080/1057031910 9374395

Beaman, A. L., Cole, C. M., Preston, M., Klentz, B., \& Mehrkens-Steblay, N. M. (1983). Fifteen years of foot-in-the-door research: A meta-analysis. Personality and Social Psychology Bulletin, 9, 181-196. doi:10.1177/0146167283092002

Burger, J. M. (1999). The foot-in-the-door compliance procedure: A multiple-process analysis and review. Personality and Social Psychology Review, 3, 303-325. doi:10.1207/s15327957pspr0304_2

Burger, J. M., Hornisher, J., Martin, V. E., Newman, G., \& Pringle, S. (2007). The pique technique: Overcoming mindlessness or shifting heuristics? Journal of Applied Social Psychology, 37, 2086-2096. doi:10.1111/j.1559-1816.2007.00252.x

Burger, J. M., \& Petty, R. E. (1981). The low-ball compliance technique: Task or person commitment? Journal of Personality and Social Psychology, 40, 492-500. doi:10.1037/0022-3514. 40.3.492

Carpenter, C. J., \& Boster, F. J. (2009). A meta-analysis of the effectiveness of the disrupt-thenreframe compliance gaining technique. Communication Reports, 22, 55-62. doi:10.1080/ 08934210903092590

Cialdini, R. B., Cacioppo, J. T., Basset, R., \& Miller, J. A. (1978). Low-ball procedure for producing compliance: Commitment then cost. Journal of Personality and Social Psychology, 36, 463476. doi:10.1037/0022-3514.36.5.463

Cialdini, R. B., \& Schroeder, D. A. (1976). Increasing compliance by legitimizing paltry contributions: When even a penny helps. Journal of Personality and Social Psychology, 34, 599-604. doi:10.1037/0022-3514.34.4.599

Davis, B. P., \& Knowles, E. S. (1999). A disrupt-then-reframe technique of social influence. Journal of Personality and Social Psychology, 76, 192-199. doi:10.1037/0022-3514.76.2.192

Dillard, J. P., Hunter, J. E., \& Burgoon, M. (1984). Sequential-request persuasive strategies: Meta-analysis of foot-in-the-door and door-in-the-face. Human Communication Research, 10, 461-488. doi:10.1111/j.1468-2958.1984.tb00028.x

Dolinski, D. (2000). On inferring one's beliefs from one's attempt and consequences for subsequent compliance. Journal of Personality and Social Psychology, 78, 260-272. doi:10.1037/ 0022-3514.78.2.260 
Feeley, T. H., Anker, A. E., \& Aloe, A. M. (2012). The door-in-the-face persuasive message strategy: A meta-analysis of the first 35 years. Communication Monographs, 79(3), 316-343. doi:10.1080/03637751.2012.697631

Fennis, B. M., Das, E. H. H. J., \& Pruyn, A. Th. H. (2004). "If you can't dazzle them with brilliance, baffle them with nonsense": Extending the impact of the disrupt-then-reframe technique of social influence. Journal of Consumer Psychology, 14, 280-290.

Fern, E. F., Monroe, K. B., \& Avila, R. A. (1986). Effectiveness of multiple request strategies: A synthesis of research results. Journal of Marketing Research, 24, 144-152. doi:10.2307/ 3151661

Goldman, M., Creason, C. R., \& McCall, C. G. (1981). Compliance employing a two-feet-inthe-door procedure. The Journal of Social Psychology, 114, 259-265. doi:10.1080/ 00224545.1981.9922755

Guéguen, N., Joule, R.-V., Halimi-Falkowicz, S., Pascual, A., Fischer-Lokou, J., \& Dufourcq-Brana, M. (2013). I'm free but I'll comply with your request: Generalization and multidimensional effects of the "evoking freedom" technique. Journal of Applied Social Psychology, 43, 116-137. doi:10.1111/j.1559-1816.2012.00986.x

Guéguen, N., Pascual, A., \& Dagot, L. (2002). Low-ball and compliance to a request: An application in a field setting. Psychological Reports, 91, 81-84. doi:10.2466/pr0.2002.91.1.81

Jones, K., Doughty, A., \& Hickson, M. (2006). The effects of age, gender, and economic status on generosity in the presence of exchange: A pilot study. Communication Quarterly, 54, 257-264. doi:10.1080/01463370600650969

Marwell, G., \& Schmitt, D. R. (1967). Dimensions of compliance-gaining behavior: An empirical analysis. Sociometry, 30, 350-364. doi:10.2307/2786181

Miller, G., Boster, F., Roloff, M., \& Seibold, D. (1977). Compliance-gaining message strategies: A typology and some findings concerning effects of situational differences. Communication Monographs, 44, 37-51. doi:10.1080/03637757709390113

O'Keefe, D. J., \& Hale, S. L. (1998). The door-in-the-face influence strategy: A random-effects meta-analytic review. Communication Yearbook, 21, 1-33.

Pascual, A., \& Guéguen, N. (2005). Foot-in-the-door and door-in-the-face: A comparative meta-analytic study. Psychological Reports, 96, 122-128. doi:10.2466/pr0.96.1.122-128

Pratkanis, A. R. (2007). The science of social influence. New York, NY: Psychological Press.

Santos, M. D., Leve, C., \& Pratkanis, A. R. (1994). Hey buddy, can you spare seventeen cents? Mindful persuasion and the pique technique. Journal of Applied Social Psychology, 24, 755764. doi:10.1111/j.1559-1816.1994.tb00610.x 